\title{
The Unmaking of Citizens
}

\author{
Shifting Borders of Belonging
}

Kristy A. Belton and Jamie Chai Yun Liew

\section{INTRODUCTION}

The world's population currently stands at 7.8 billion, and every day millions are born who automatically acquire the citizenship of a particular state. Few question the routineness of the citizenship acquisition process (whether through a citizen parent or through birth on a specific state's territory). Even fewer question the necessity of possessing citizenship or the state's sovereign right to determine who should belong and how. We generally take the particular rights, freedoms, and protections associated with citizenship for granted and cannot fathom what a world without citizenship, at least as currently conceived, would look like. Yet citizenship is not necessarily a neutral and stable status upon which to base rights, freedoms, and protections. It is also not a status available to all. As this chapter illustrates, citizenship is precarious and has never been a secure foundation upon which to base human rights. In the securitized world of the twenty-first century, this instability has heightened, especially for minorities.

To make this argument, the chapter is divided into three sections. The first section explains how citizenship arose in international practice and law and how states translated international practice into defined nationality laws in the domestic sphere. This section highlights how, before it became a status to which human rights attached, citizenship was, first and foremost, an international ordering principle. The second section demonstrates how states have historically excluded various groups, typically minorities, from enjoyment of full citizenship status, thereby endangering the access of these groups to human rights enjoyment. The third section provides contemporary examples of citizenship deprivation and denial, highlighting the myriad justifications that states use to deny and deprive people of citizenship. 


\section{CITIZENSHIP IN INTERNATIONAL AND DOMESTIC LAW}

Citizenship may be understood in many ways. For the purpose of this chapter, it is defined as the legal bond of attachment between a person and a state. It serves as a mobile border, demarcating who is from where and how said person should be treated when outside the borders of her state. In the modern era, it has become an international ordering principle, which rests on the notion of states as self-contained political units that govern defined territories. The emergence of sovereign, independent states that governed their own internal affairs is typically traced to Europe and the Peace of Westphalia, which ended the Thirty Years' War. ${ }^{1}$ The peace treaties cemented the demise of the overarching power of the Catholic Church and the Holy Roman Empire and heralded the advent of an international legal system where autonomous states became masters of their own domain and recognized each other's authority over territory. ${ }^{2}$

Although many trace the beginning of the present international world order to the Peace of Westphalia, scholars acknowledge that the concepts of statehood and state sovereignty were not simply constructed, endorsed, and applied at this point in time. Instead, the treaties sanctioned or confirmed an interstate system that was already developing, or in existence, out of necessity as a consequence of negotiating peace. ${ }^{3}$ State sovereignty thus emerged as the dominant organizing principle of the Peace of Westphalia because of the growing recognition that polities were organizing themselves in this way.

Furthermore, these peace treaties not only addressed authority over territory but also endorsed authority over individuals, referring to "vassals," "subjects," "soldiers," "inhabitants," "servants," "people," and others. ${ }^{4}$ Passages referring to such people in the peace treaties were written with the intention to provide protection. That is, state sovereignty included not only the unencumbered right to rule over people but the reciprocal responsibility of protecting them as well.

What began as political practice in early Europe solidified in international legal doctrine in the 1930s. The 1930 Convention on Certain Questions Relating to the Conflict of Nationality Law established that it was "in the general interest of the international community to secure that all its members should recognize that every

1 Although this system of international law started in Europe, other polities were folded into this new world order through the expansion of European colonial empires. Polities that were not colonized reluctantly adopted this European model. As a result, by the early twentieth century, the European model of international legal order was universalized.

2 J. H. Currie, Public International Law (2nd ed., Toronto: Irwin Law, 2008).

3 D. Croxton, "The Peace of Westphalia of 1648 and the Origins of Sovereignty" (1999) 21(3) The International History Review 569-591.

4 The Peace of Westphalia comprises a series of treaties signed between May and October 1648 in the cities of Osnabrück and Münster. See, for example, Treaty of Münster (Peace Treaty between the Holy Roman Emperor and the King of France and their respective Allies), October 24, 1648, http://avalon.law.yale.edu/17th_century/westphal.asp. 
person should have a nationality," ${ }^{5}$ and it did not permit the loss of citizenship unless (or until such time that) a person acquired another one. Only a few years later, the 1933 Montevideo Declaration articulated that one of the criteria for statehood was the existence of a permanent population. This permanent population became the citizenry. Later United Nations human rights treaties ${ }^{6}$ would institute the significance of citizenship through the establishment of a human right to a nationality. ${ }^{7}$

Citizenship is so important from an international legal framework that no right to be voluntarily stateless (without citizenship) exists; states are not allowed to deprive an individual of citizenship arbitrarily; and states are prohibited from allowing their citizens to become charges on other states. Citizenship is thus much more than a conduit for rights access. It is the basis upon which states formally set the borders of belonging and through which they are able to conduct what Ceciliano-Navarro, Golash-Boza, and Rubén González call a "global apartheid" in Chapter 6. Despite the importance of citizenship as an international ordering principle, no international organization exists, whether as creator, arbiter, or enforcer, of citizenship laws for any state. Instead, the state has the "reserve domain," or final say, on whether to grant, deny, or revoke citizenship, and on crafting the laws, processes, and legal institutions under which a person is deemed to be a citizen. It is within this "sovereign" space that the gap between the international human right to citizenship and its enjoyment in practice is most evident.

In general, there are two main ways to acquire citizenship globally: by birth and, to a lesser extent, through naturalization. Birthright citizenship can be obtained (a) by being born within a state or its territories (jus soli) or (b) by being born to a parent who has a particular citizenship (jus sanguinis). All countries around the world offer a form of jus soli or jus sanguinis citizenship, but not all provide it absolutely. Exceptions vary. In the jus soli arena, for example, states exclude birthright citizenship to children born of foreign diplomats. And in places such as the Dominican Republic, children born in the country to parents who are classified as "in transit,"

5 Convention on Certain Questions Relating to the Conflict of Nationality Law, July 1, 1937, 179 L.N.T.S. 89. Articles 5 -7 of the Convention on the Reduction of Statelessness, August 30, 1961, 989 U.N.T.S. 175, https://legal.un.org/ilc/texts/instruments/english/conventions/6_1_1961.pdf, also reiterate these principles.

6 Citizenship and nationality are used interchangeably in this text, as is the practice in much of the literature on citizenship and statelessness.

7 United Nations treaties that address the right to a nationality include the International Convention on the Elimination of All Forms of Racial Discrimination, December 21, 1965, 66。 U.N.T.S. 195, art. 5; the International Covenant on Civil and Political Rights, December 16, 1966, 999 U.N.T.S. 171, art. 24; the Convention on the Rights of the Child, November 20, 1989, 1577 U.N.T.S. 3, art. 7; the Convention on the Elimination of All Forms of Discrimination against Women, December 18, 1979, 124 U.N.T.S. 13, art. 9; the International Convention on the Protection of the Rights of All Migrant Workers and Members of Their Families, December 18, 1990, A/RES/45/158, art. 29; and the Convention on the Rights of Persons with Disabilities, January 24, 2007, A/RES/61/106, art. 18. 
which includes people with expired residency visas and undocumented workers, are excluded from acquiring citizenship via jus soli.

Still other states provide that both jus soli and jus sanguinis criteria must be met. For instance, France limits birthright citizenship to children born in France to a French parent or to a parent also born in France. Finally, some states offer a graduated process by which children born in the state to noncitizen parents may be eligible for citizenship by a certain age once residency requirements are fulfilled. For example, Israel allows persons between the ages of eighteen and twenty-one to acquire citizenship if they were born in Israel and resided there for more than five years. States such as Cambodia and Germany, on the other hand, only confer jus soli citizenship if a child is born to noncitizens who are residing there legally.

When it comes to jus sanguinis or acquisition of citizenship by "right of blood," restrictions may include limiting citizenship to the first generation or to those born of a citizen father. Canada, for example, limits jus sanguinis to the "first generation." Thus, if a Canadian citizen, who herself was born outside Canada, gives birth to a child outside Canada, her child will not be Canadian. In the Bahamas, only male citizens can pass on their citizenship to children born outside the country if they are married to a noncitizen. Bahamian women married to noncitizens who give birth to children outside the Bahamas have no similar right to pass on their citizenship. Numerous other exceptions exist that illustrate how citizenship is not an automatically acquired status for all at birth and is, therefore, an inadequate foundation upon which to base human rights. Furthermore, as the next section illustrates, states also exclude certain groups from citizenship when it serves their interests.

\section{CITIZENSHIP AND ITS EXCLUSIONS}

States have long erected barriers, indirectly and directly, to citizenship. Throughout history, and in modern times, legal categories of exclusions or exceptions have been created to prevent certain people from acquiring citizenship and to provide normative strength to the idea that only some are purportedly deserving of citizenship. In many cases, some may experience exclusion by virtue of intersecting statuses because they are an Indigenous person who is also a woman, or a person who is of an ethnic minority group that has also been deemed a security risk to the state (consider the Kurds, for example). What follows are a few examples of groups who have not always found themselves fully captured within the state's borders of formal belonging. Many are, as Tendayi Bloom discusses in Chapter 10, individuals who are in both a citizen and a noncitizen relationship to the state.

\section{Indigenous Peoples}

Despite already living on the land when Europeans arrived, Indigenous peoples have not always been considered legal citizens of colonizing states. In Canada, for 
example, although the 1947 Citizenship Act provided that British subjects born in Canada prior to 1947 were Canadian citizens, First Nations and Inuit were not considered British subjects and therefore were not considered citizens. Furthermore, colonial governments created differential statuses for Indigenous peoples. In Canada, the Indian $\mathrm{Act}^{8}$ created a system of reserves and registered Indigenous persons and defined how the Canadian government would treat certain Indigenous persons. A similar story played out in the United States and Australia where Native Americans and Aborigines were excluded from citizenship for much of these states' early history. ${ }^{9}$ Indigenous peoples' experience thus shows how the law has constructed persons as not citizens or produced their citizenship in ways that differ from their legal traditions or entitlements.

\section{Ethnic and Racial Minorities}

States have also enacted measures to restrict access to citizenship to racialized persons or persons with a particular ethnicity. In the United States and Canada, for example, Asian people were subject to open hostility and discrimination that led to the enactment of legislation to prevent them from coming to North America. In the United States, the 1882 Chinese Exclusion Act prevented Chinese immigration to the United States. ${ }^{10}$ Canada followed the Americans by first issuing a report by the Canadian Royal Commission on Chinese and Japanese Immigration that stated Asians were "unfit for full citizenship ... obnoxious to a free community and dangerous to the state."11 Following this report, the Canadian Parliament voted to increase the Chinese head tax to $\$ 500$, an entrance fee meant to deter the migration of Chinese people to Canada. Furthermore, during the Second World War, Japanese Canadians and Japanese Americans were interned in concentration camps all over North America. The experience of ethnic and racial minorities, also explored in Chapter 6 in the context of migration, highlights how the law can be used to actively discriminate against certain groups and prevent them from becoming citizens.

\section{Women}

Women, who typically make up more than half of any state's population, have historically been treated differently when it comes to the ability to acquire or lose

8 Indian Act, Revised Statutes of Canada, 1985, c I-5.

9 Note that with the passage of the US Indian Citizenship Act, June 2, 1924, Indigenous peoples, whether or not they wanted to become US citizens, were forced to become so.

${ }_{10}$ An Act to Execute Certain Treaty Stipulations Relating to the Chinese, May 6, 1882.

${ }^{11}$ Privy Council Office of Canada and the Canadian Royal Commission on Chinese and Japanese Immigration into British Columbia, Report of the Royal Commission on Chinese and Japanese Immigration (Ottawa: S. E. Dawson, 1902), http://publications.gc.ca/site/eng/9 $.824969 /$ publication.html. 
citizenship, as well as to confer citizenship on their children. Historically, women were seen as the property of male citizens. As a consequence, they often lost their birthright citizenship upon marriage to a noncitizen because they were assumed to have taken on the foreign husband's citizenship. Although the 1957 Convention on the Nationality of Married Women prohibited this practice, ${ }^{12}$ gender discrimination in nationality laws remains a problem today. Twenty-seven countries deny mothers the equal right to confer nationality on their children and around fifty have other gender-discriminatory nationality provisions that place their female citizens on an unequal footing with their male counterparts. Women's citizenship history and experience illustrate the property-like features of citizenship and underscore the patriarchal current that undergirds it.

\section{The Stateless}

Stateless people, or those who are not recognized under the operation of any state's nationality law, typically are born and reside within a state that excludes them from citizenship. More than fifteen million people are estimated to be stateless globally. They suffer a host of human rights violations and impingements upon their ability to be self-determining agents because they are citizens of nowhere. ${ }^{13}$ Although multiple pathways to statelessness exist, ${ }^{14}$ no international norm exists recognizing a person's right to be voluntarily stateless. In fact, international law is clear that each person should have a citizenship and that before a person is stripped of citizenship, she or he must have access to another state's citizenship first.

Even before the Universal Declaration of Human Rights asserted each person's right to a nationality, the 1930 Convention on Certain Questions Relating to the Conflict of Nationality Law established that it was "in the general interest of the international community to secure that all its members should recognize that every person should have a nationality." ${ }^{15}$ Akin to the later ${ }_{1961}$ Convention on the Reduction of Statelessness, the 1930 Convention does not permit the loss of citizenship unless or until such time that a person acquires another one. ${ }^{16}$ Despite this, many states have resisted conferring citizenship on stateless persons, claiming they

${ }^{12}$ Convention on the Nationality of Married Women, February 20, 1957, 309 U.N.T.S. 65, https://treaties.un.org/doc/Treaties/1958/08/19580811\%2001-34\%20AM/Ch_XVI_2p.pdf.

${ }^{13}$ See K. A. Belton, Statelessness in the Caribbean: The Paradox of Belonging in a Postnational World (Philadelphia: University of Pennsylvania Press, 2017); K. A. Belton, "Statelessness: A Matter of Human Rights," in R. Howard-Hassmann and M. Walton-Roberts (eds.), The Human Right to Citizenship: A Slippery Concept (Philadelphia: University of Pennsylvania Press, 2015), pp. 31-42.

${ }^{14}$ See Belton, Statelessness in the Caribbean, pp. 30-38.

15 Convention on Certain Questions Relating to the Conflict of Nationality Law, July 1, 1937, 179 L.N.T.S. 89.

${ }^{16}$ Ibid., art. 7; Convention on the Reduction of Statelessness, August 30, 1961, arts. 5-7. 
are the citizens of other states even though they have no citizenship by operation of law to any state. The next section describes how even those with citizenship status may fall on the wrong side of state interests and lose this purportedly fundamental status.

\section{CITIZENSHIP DEPRIVATION}

It is one practice to deny individuals citizenship, ${ }^{17}$ as in many of the aforementioned examples, and it is another practice to deprive individuals of the citizenship they hold. Citizenship deprivation (or withdrawal) ${ }^{18}$ has its roots in former practices of exile and banishment. Although states are no longer permitted to allow their citizens to become charges on other states, they are allowed to withdraw citizenship on a number of grounds, including committing a crime or engaging in acts deemed "threatening" or "disloyal" to the state, seeking refuge elsewhere, converting to another religion, or failing to renew a passport, among other reasons. ${ }^{19}$

Moreover, the ${ }_{1961}$ Convention on the Reduction of Statelessness, ${ }^{20}$ which aims to reduce statelessness globally, is clear that citizenship deprivation is permissible when an individual has acted "inconsistently with his duty of loyalty to the Contracting state" by rendering services to another state, acting in a way that is "seriously prejudicial to the vital interests of the state," or declaring allegiance to another state, among other reasons. ${ }^{21}$ As long as these grounds are not "arbitrary" (and it is not always clear what a state will deem arbitrary in practice), the state has the sovereign right to deprive a person of his/her citizenship and render the individual stateless. ${ }^{22}$ Moreover, states that engage in citizenship withdrawal typically deny that they are rendering individuals stateless. They argue that the individuals deprived of citizenship are dual nationals or have the ability to apply for citizenship in another state through operation of that other state's law. As the following examples show, however, this is not always the case.

17 Citizenship denial largely consists of preventing access to citizenship, whether through the refusal to grant identity documents (such as birth certificates) or the refusal to apply a given law to an individual to recognize him/her as a citizen.

${ }^{18}$ It is also known as citizenship stripping, citizenship revocation, denationalization, and denaturalization. Denationalization occurs when citizenship is taken away from someone who acquired citizenship through jus soli or jus sanguinis measures. Denaturalization occurs when citizenship is taken away from a naturalized citizen.

19 See Belton, Statelessness in the Caribbean, pp. 30-38.

${ }_{20}$ Convention on the Reduction of Statelessness, August 30, 1961,.

${ }^{21}$ Ibid., art. 8.3(a).

${ }^{22}$ See S. Jaghai, "Citizenship Deprivation, (Non) Discrimination and Statelessness: A Case Study of the Netherlands (Institute on Stateless and Inclusion, 2017)," p. 9, https://files.institutesi.org/ WP2017_07.pdf. As Jaghai observes, "There seems to be tension in the application of international law at the domestic level regarding the principle of non-discrimination and the prohibition that deprivation of nationality cannot lead to statelessness" (ibid., p. 14). 


\section{National Security}

Despite the permissibility of citizenship deprivation in the international arena, and the fact that states have occasionally engaged in this practice historically, ${ }^{23}$ it is only recently that citizenship deprivation laws have been more vigorously implemented and strengthened, and that countries that previously had no such laws have begun to introduce them. States are now looking to "nationality policy as a tool to tackle emerging national security threats."24 For example, Austria, Azerbaijan, Bangladesh, Belgium, Israel, Russia, the Netherlands, the United Kingdom, the United States and others have either introduced citizenship deprivation measures in response to perceived national security threats or begun to more systematically apply and strengthen existing citizenship deprivation laws. ${ }^{25}$

The heightened security environment that ensued post $9 / 11$ has allowed states to situate citizenship deprivation within a national security and crimmigration ${ }^{26}$ policy rationale that challenges the permanency of citizenship and turns citizens into deportable foreigners or "dangerous aliens." 27 In this sense, citizenship deprivation has conceptually pushed citizenship into the realm of privilege rather than a right, and citizenship revocation has become a punitive tool. ${ }^{28}$ Although the threat of a foreign enemy has always operated within a state's modus operandi, the figure of the foreign enemy is now extended to those that hold citizenship in Western states as part of the emergence of "homegrown" terrorism. ${ }^{29}$ The identification of such "enemies" within has given Western states in particular the impetus to create and use legal mechanisms to engage in citizenship deprivation. ${ }^{30}$

Revocation grounds and proceedings vary by country. Some countries have legal provisions to denaturalize a citizen who obtained citizenship through fraud or misrepresentation. This is known as "civil denaturalization" in the United States

${ }^{23}$ See Belton, Statelessness in the Caribbean, chapter 2.

${ }^{24}$ L. van Waas and S. Jaghai, "All Citizens Are Created Equal, but Some Are More Equal Than Others" (2018) 65 Netherlands International Law Review 413-430 at 419.

${ }^{25}$ See ibid.; S. Pillai and G. Williams, "Twenty-First Century Banishment: Citizenship Stripping in Common Law Nations" (2017) 66 International and Comparative Law Quarterly 521-555. Both articles provide extensive details on the ways in which states are using citizenship withdrawal as a national security measure.

${ }^{26}$ J. Stumpf, "The Crimmigration Crisis: Immigrants, Crime, and Sovereign Power" (2006) 56(2) American University Law Review 367. Stumpf first coined this term to discuss the merging of criminal and immigration law where migrants are being criminalized through the immigration system.

${ }^{27}$ A. Macklin, "Citizenship Revocation, the Privilege to Have Rights and the Production of the Alien” (2014) 40(1) Queens Law Journal 1-54. See also Chapter 6.

${ }^{28}$ S. Lavi, "Citizenship Revocation as Punishment: On the Modern Duties of Citizens and Their Criminal Breach" (2011) 61(4) Constitutionalism and the Criminal Law 783-810.

29 C. Forcese, "A Tale of Two Citizenships: Citizenship Revocation for "Traitors and Terrorists" (2014) 39(2) Queens Law Journal 551-570.

30 P. Lenard, "Democracies and the Power to Revoke Citizenship" (2016) 30(1) Ethics and International Affairs 73-91. 
and was practiced under the administrations of both George W. Bush and Barack Obama, but it has increased, and become further institutionalized, under Donald J. Trump's administration. For instance, in February 2020, the US Department of Justice established a "Denaturalization Section," which purportedly targets "terrorists, war criminals, sex offenders, and 'other fraudsters."'31

Increasingly, legislation is being amended to include reasons of national security, broadly worded, to encompass a wide array of threats or activities. One prominent and recent example is Jack Letts, more popularly known as "Jihadi Jack." Letts was a dual citizen of the United Kingdom and Canada. Letts was reportedly raised in the United Kingdom, converted to Islam at the age of sixteen, and joined ISIS, or the Islamic state abroad, a jihadist terror group known for its brutal mass killings. ${ }^{32}$ Letts' overseas activities are not substantiated, but in an interview with $\mathrm{BBC}$, he stated that he was an enemy of the United Kingdom, that he thought he was doing something good, and that he had made a big mistake. ${ }^{33}$ While he was imprisoned in a Kurdish jail in northern Syria in August 2019, the United Kingdom revoked Letts' citizenship.

The move to strip Letts of UK citizenship blindsided Canada. The Minister of Public Safety in Canada commented, "Canada is disappointed that the United Kingdom has taken this unilateral action to off-load their responsibilities," but also added that they had "no legal obligation to facilitate" the return of Canadian citizens detained in Syria. ${ }^{34}$ Former defense minister of the United Kingdom, Tobias Ellwood, agreed, stating that citizenship revocation "shunts the responsibility elsewhere" when many persons were "radicalised here in the UK." 35 The UK Home Office held, however, that "[t]his power is one way we can counter the terrorist threat posed by some of the most dangerous individuals and keep our country safe." 36

While Letts is fortunate because he held dual citizenship, there are two normative implications to the United Kingdom's move to revoke citizenship of someone it deems as a terrorist threat. The first is that it legitimizes the very act of revocation even where it does not leave a person stateless. It thus makes citizenship probationary and precarious. Second, it legitimizes the use of citizenship deprivation as a form of banishment or punishment and allows the state to avoid responsibility for the acts of its citizens.

${ }^{11}$ R. Prasad, "What Does Trump's New Denaturalisation Section Do?” BBC News, February 28, 2020, www.bbc.com/news/world-us-canada-51681840.

32 D. Sabbagh, “Jack Letts Stripped of British Citizenship," The Guardian, August 18, 2019, www .theguardian.com/world/2019/aug/18/jack-letts-stripped-british-citizenship-isis-canada; "Jihadi Jack: IS Recruit Jack Letts Loses UK Citizenship,” BBC News, August 18, 2019, www.bbc. com/news/uk-49385376.

33 "Jack Letts, Islamic State Recruit: 'I Was Enemy of UK," BBC, June 21, 2019, www.bbc.com/ news/uk-48624104.

34 “Jihadi Jack: IS Recruit Jack Letts Loses UK Citizenship."

35 Ibid.

${ }^{6}$ Ibid. 
Another prominent but more problematic example is that of Shamima Begum, a twenty-year-old woman who at age fifteen left the United Kingdom to join the Islamic state. ${ }^{37}$ In February 2019, the United Kingdom revoked her citizenship. The Special Immigration Appeals Commission, a tribunal that hears national security cases, reasoned that Begum could be stripped of her citizenship because she would not be left stateless despite the fact that Bangladesh had stated that it did not recognize her as a citizen..$^{8}$ The Commission held that Begum was "a citizen of Bangladesh by descent." 39 Begum's lawyer has appealed the decision.

This practice reinforces the normative move to legitimize citizenship deprivation where national security concerns exist, but, troublingly, it also shows how the legal definition of statelessness may be eroding. In particular, the legal finding that Begum was a national of another state was not based on any evidence, but on speculation that she could be granted citizenship by another state (in this case, Bangladesh) by an examination of its laws.

\section{Criminal Behavior}

Aside from national security or terrorism concerns, citizenship withdrawal may be premised upon individuals' criminal behavior. Take for example the case of Canada v. Budlakoti..$^{\circ}$ Budlakoti was born and raised in Canada. Due to his criminal convictions, Budlakoti was found inadmissible under Canada's Immigration and Refugee Protection Act. Budlakoti challenged this finding by asserting he was a Canadian citizen. The Immigration Division of the Immigration and Refugee Board (IRB), however, held that he was not a citizen as per the Citizenship Act since he fell into the exception that children born of parents under the employment of a foreign government do not enjoy birthright citizenship.

The Immigration Division determined that Budlakoti's parents were working for officials of the Indian Consulate in Canada at the time he was born, therefore making him ineligible for citizenship by birth. Budlakoti unsuccessfully challenged this decision. In asserting he would be stateless as a result of the Immigration Division's findings, the Federal Court of Appeal held that "[h]e is not yet stateless" since Budlakoti "can take steps to apply for citizenship in India and in Canada." This finding is particularly troubling given that the Court acknowledged that the Indian Consulate had refused to recognize Budlakoti as a citizen and that the Canadian government was involved in litigation to make him removable from Canada.

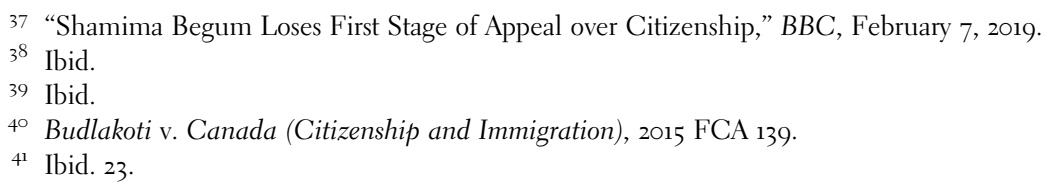




\section{Minority Status}

States have also used the tool of citizenship deprivation against political opponents, human rights defenders, protestors, and minority groups (as defined by their religion, ethnicity, race, or culture). For example, Rohingya have been stripped of their citizenship and denied any entitlement to citizenship in Myanmar since 1982. Many Rohingya are stateless as a result of a deliberate change in citizenship law that turned them into illegal immigrants within their own country. The loss and denial of citizenship is not a benign act. At a minimum it means Rohingya cannot open a bank or a cell phone account, register births, marriages or deaths, and, more seriously, it has also meant difficulties in accessing health care, education, employment, and freedom of movement.

More concerning is that citizenship deprivation has cast the Rohingya as outsiders and justified their oppression and institutionalized exclusion, leading to genocide. The state has thus harnessed the legal fact of statelessness to engage in violence, displacement, and killing of its Rohingya population. Indeed, on January 23, 2020, in response to legal action taken by Gambia, which had accused Myanmar of genocide, the International Court of Justice took a significant step by issuing a preliminary order that instructed Myanmar to take immediate measures to prevent the genocide of its stateless Rohingya Muslim minority. ${ }^{42}$

Citizenship withdrawal also takes on an ethnic dimension in the Dominican Republic, which has a long history of discriminating against individuals of Haitian descent among its citizenry. In 2013, the Dominican state systematically institutionalized this discrimination by revoking the citizenship of approximately 200,000 Dominicans of Haitian descent through Constitutional Court decision TC/o168/ $13 .{ }^{43}$ This decision permitted civil registries to audit birth registry books as far back as 1929 to find out whether a person's ancestor had used a non-authorized document ${ }^{44}$ to secure a legal status within the Dominican state. If said ancestor was deemed to have used an unauthorized document, then that person's Dominican descendants were stripped of citizenship.

Due to international concern about the judicial decision and its retroactive effect, the Dominican government implemented a path to regularization for those citizens

$4^{2}$ Application of the Convention on the Prevention and Punishment of the Crime of Genocide (The Gambia v. Myanmar) (January 23, 2020), www.icj-cij.org/en/case/178/orders.

43 Sentencia TC/o168/13, Dominican Republic: Constitutional Court (September 23, 2013), www .refworld.org/cases,DR_CC, $526900 c 14 . h t m l$.

44 There has been much debate on whether the permits that granted individuals the right to work on the sugarcane plantation served as "authorized" documents or not. For more on citizenship deprivation in the Dominican Republic, see Belton, Statelessness in the Caribbean, chapter 4. For information on how similar discriminatory civil registries practices play out in the Malaysian context, see J. Liew, "Homegrown Statelessness in Malaysia: The Administratively Stateless and the Promise of the Principle of Genuine and Effective Links" (2019) 1(1) Statelessness and Citizenship Review 95-135. 
who had been rendered stateless. This regularization plan created different classes of denationalized persons, led to the deportation of many, and has yet to fully restore citizenship to those who have legitimate claims to it.

Whereas in the Dominican case a regularization plan was established for those stripped of citizenship, Bahrain has chosen deportation for many of those it has stripped of citizenship. Since 2012, at least 990 Bahrainis have lost their citizenship through court decisions or executive orders, leaving most persons stateless and leading to their deportation. Among those stripped of citizenship are human rights defenders, political activists, journalists, and religious scholars. Recently, a mass trial convicting 139 people of terrorism charges led to the wholesale revocation of citizenship of those persons. This trial demonstrates that Bahrain's authorities are increasingly relying on citizenship withdrawal as a tool of repression and as a means to eliminate opposition.

\section{CONCLUSION}

Although citizenship as a status is an accepted international ordering principle, it is not, and never has been, a status that is equally accessible to all. For those who were denied citizenship from birth, citizenship has always been unattainable. For others, their belonging to a particular minority group - both historically and today - has prevented their access to full citizenship in practice, even if they were (or are) nominally recognized as citizens under domestic law. Citizenship is not only unevenly applied as a principle in practice, but it is not a stable, enduring, or permanent status either. Those who have been stripped of citizenship under the rationale of national security and other such prerogatives can attest to this.

Perhaps citizenship was never meant to be more than an international ordering principle of people(s) and we have tied notions of human rights, equality and justice to a concept that was never built to hold them. As several authors in this volume attest, concepts of citizenship and noncitizenship perpetuate distorted perceptions of who belongs and how they should be treated. In essence, by bestowing states with the sovereign prerogative to define who belongs where, we have allowed an exclusionary and precarious status to hold far too much influence over people's life chances and furthered global conditions of injustice. 